\title{
SCIENTIFIC DIASPORA AS A DRIVING FORCE FOR DEVELOPMENT IN SERBIA
}

\author{
Srećko R. Stopić ${ }^{a}$, Robert Đ. Kozma ${ }^{b}$, Tanja J. Pavlov ${ }^{b}$ \\ a IME Process Metallurgy and Metal Recycling, \\ RWTH Aachen University, Germany \\ ${ }^{\text {b }}$ Group 484, Belgrade, Serbia
}

FIELD: Materials

DOI: 10.5937/vojtehg61-3904

ARTICLE TYPE: Review Paper

\begin{abstract}
:
In the light of contemporary forms of migration and in the context of globalisation and rapid development of technology and transportation, diaspora is increasingly viewed through the transnational prism. Instead of forcedly scattered countrymen, who dream of returning to their homeland and have difficulties with the integration in the reception country, diaspora is seen as a link that connects worlds, the country of origin and the receiving country, thus enabling migration to be used for development of the community and society on the whole. Instead of return, the emphasis is on the circular exchange and transnational mobility. In this way countries of Southeast Europe are trying to transform the "brain drain", which was particularly prominent in the 1990s, into "brain circulation" and "brain gain". In Serbia, 1990s migration was triggered by saving lives, primarily from the painful and bloody civil wars waged in the former Yugoslavia, international isolation and NATO bombing, as well as the difficult economic situation. In that period, the particularly massive departure was that of young and educated people with the generally accepted slogan "to graduate, and then to emigrate". However, migration of educated people and professionals, often motivated by career development and professional advancement abroad, has continued after 2000. Many young people are enabled to go abroad with the help of foreign scholarship foundations aiming at assisting development in Serbia, such as the Alexander von Humboldt Foundation AvH, German Academic Research Service DAAD, Mummert Foundation, etc. Therefore, the main objective of this paper is to determine the possibility for connection between professionals from diaspora and young students and engineers in Serbia, in order to facilitate the transfer of knowledge and their mobility and thus prevent the irreversible loss for the country. In addition to theoretical considerations of the possibility to improve cooperation with the diaspora, the paper analyses an example of successful cooperation between professionals in the metallurgical industry from
\end{abstract}

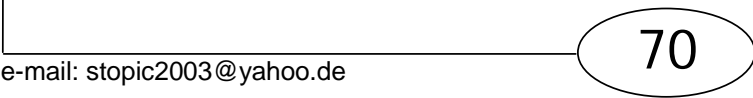


Germany and professionals from Serbia, initiated by a representative of the professional diaspora. Finally, recommendations are made as to how to apply the lessons learned from the literature and practice for the development of sustainable cooperation among the professional diaspora and youth and professionals in Serbia.

Key words: scientific potential; brain drain; metallurgy; diaspora.

\section{Introduction}

T he debate about the brain drain and gain has been running long in the scientific and professional circles, driven by the needs and policies of developed countries. In the 1950s and 1960s, the years of rapid economic expansion and low population growth in Europe, there was a need for immigrant labour and programmes for their recruitment were developed. During that period, the functionalists inspired by neo-classical economics of migration were spreading optimism, speaking about the role of migration in development and modernisation of society, about the "balanced growth" and the brain gain (De Haas 2008: 23). In the 1970s and 1980s, the years characterised by the oil crisis, economic recession and rising unemployment, European governments lifted the labour recruitment programmes and introduced new, more restrictive immigration policies. During that period, the structuralists, relying on the Marxist political economy and world-systems theory, offered a pessimistic picture (De Haas 2008: 28). They pointed to the increasing underdevelopment and dependency of the countries that "send" migrants and the "asymmetrical development" and the brain drain, as a consequence of migration. In the 1990s, the consolidation of Western Europe as a free internal market, more developed and cheaper means of communication and transport and the need for highly qualified labour force were accompanied by the creation of win-win concepts transnationalism (Glick Schiller, Basch and Blanc-Szanton 1992, Morawska 2003, Portes 1997, 2001, Vertovec 2009) and "brain circulation" (Kuznetsov 2006, Saxenian 2005, Xiaonan 1996).

The first definition of transnationalism included: "the process by which transmigrants, through their daily activities, forge and sustain multi-stranded social, economic, and political relations that link together their societies of origin and settlement, and through which they create transnational social fields that cross national borders". (Basch et al. 1994: 6)

This definition and the concept as a whole have gone through a number of debates and criticism. The narrowness of the definition has been pointed to, as well as the vagueness and inadequacy of the term, the exaggeration in the scope of phenomena, the lack of novelties in this concept, etc. (Bozic 2004, Kuti and Bozic 2011, Portes 2001, 2003, 
Waldinger, Fitzgerald 2004). Yet the transnational perspective is important because it has changed the perception of migration as a static phenomenon in the form of a one-way movement induced by pull and push factors, eliminated the current dichotomies and allowed observation of more complex and fluid forms of contemporary migration (Portes 2001, Morokvašić, 2011). It has also contributed to solving the brain drain-gain dilemma and the introduction of brain circulation: the mobility of HSP ('highly skilled personnel') who have marketable expertise and international experience and who tend to migrate for the short term or make temporary business visits in a country (or countries) where their skills are needed. (Xiaonan 1996: 275)

The mobility of highly qualified people and their transnational activities have become apparent in Serbia, but the question is to what extent brain circulation is achieved in terms of application of knowledge, skills and contacts acquired abroad throughout the transnational space for its economic and democratic development.

\section{Brain Drain in Serbia: Scope of the Phenomenon and Policies}

In Serbia, the migration of highly qualified people can be divided into migration before and after 2000, the year of political changes in the country (Pavlov and Rakic 2011, Pavlov 2011). In the period 1990-2000, migration was triggered by saving lives, primarily from the painful and bloody civil wars that were waged in the former Yugoslavia, international isolation and NATO bombing, as well as the difficult economic situation, e.g. in 1993, the inflation rate was 400,000,000,000,000 per cent (Belgrade Centre for Human Rights, 2000). In that period, the particularly massive departure was that of young and educated people with the generally accepted slogan "to graduate, and then to emigrate". It is estimated that during the 1990s 5 per cent of the total population left Serbia, which is higher than in earlier decades - 19712.5 per cent, 1981 - 3.6 per cent, 1991 - 3.9 per cent, and they left it for a long period, many of them permanently (Bolčić 2002: 160). After 2000, there was also migration motivated by career development and professional advancement abroad. The Strategy of Scientific and Technological Development of Serbia 2010-2015 (2010: 15) states that 19,000 highly skilled people have left Serbia since 1990. On the other hand, Docquier and Rapoport (2011: 7) have presented data for 2000 that Serbia and Montenegro of that time, with 161,885 highly skilled immigrants was among the top 30 countries of the world, which is in line with the OECD data (2008: 87) of 11.5 per cent, or 120,060 tertiary educated out of the total of $1,044,000$ foreign-born population from Serbia and Montenegro living in 
OECD countries. Filipovic (2012) has developed database with 7000 Serbian scientists in diaspora. They are people in their prime working age between 30 and 36 (Grečić, Lopušina 1994: 121), primarily from the technical-technological (information technology) and natural sciences. America, Canada and Western European countries are their most common destination countries (Beogradski centar za ljudska prava, 2001).

In spite of the severity of the brain drain phenomenon, Serbia, which in the $19^{\text {th }}$ century had a strategy for creating educational elite by sending young people to education abroad in line with the needs of government services (Trgovčević 2003), now lacks a developed systemic approach to encouraging brain circulation and brain gain. Measures to improve working conditions for scientists and researchers in the country, developing cooperation with professional diaspora, encouraging mobility and return of professionals are scattered in various strategies, the realisation of which is the responsibility of different actors. They are included in seven strategies: Strategy for Migration Management (2009), Strategy of Scientific and Technological Development of Serbia for the period 2010-2015, Strategy to Preserve and Strengthen the Relationship between the Homeland and Diaspora, as well as Homeland and the Serbs in the Region, National Youth Strategy, National Strategy for Economic Development of Serbia 2006-2012, National Sustainable Development Strategy 2007-2017 and the Regional Development Strategy of Serbia 2007-2012. Nevertheless, these strategies are generally (except for the youth strategy and the strategy for the diaspora) not applied in the part relating to highly educated migrants, due to the lack of knowledge about this type of migration and the lack of financial resources.

However, there are some good examples of brain gain activities and projects - mobility programmes, scholarships, cooperation with the diaspora and support to the return of the diaspora (Pavlov, Rakic 2011). Therefore, we will present an example of good practice - German mobility and scholarship programmes.

\section{Example of Good Practice: German-Serbian cooperation}

Good examples of activities that facilitate brain gain and brain circulation are the activities of Alexander von Humboldt Foundation (AvH) and German Academic Exchange Service (DAAD). Alexander von Humboldt Foundation is "an intermediary organization for German foreign cultural and educational policy that promotes international cultural dialogue and academic exchange". ${ }^{1}$ The Foundation offers research fellowships and

\footnotetext{
${ }^{1}$ http://www.humboldt-foundation.de/web/about-us.html, accessed 26/04/2013.
} 
research awards to young postdoctoral researchers but also to experienced academics, or even world authorities in some discipline. The German Academic Exchange Service (DAAD) is "the largest funding organisation in the world supporting the international exchange of students and scholars." ${ }^{2}$ DAAD gives opportunities for research grants and exchange programmes. Through these programmes, cooperation among German and Serbian academics and researchers has been developed (Srecko Stopic 2008, 2009). AvH Foundation, besides research grants, has supported many expert meetings of Serbian and German researchers and academics (Figure 1). For example, the Foundation will support the meeting "Resources of Danubian region: the possibility of cooperation and utilization" that will be organised in June, 2013 in Belgrade.

The Project Based Personnel Exchange Programme is a bilateral research promotion programme that is a result of the agreement concluded between the German Academic Exchange Service DAAD and the Serbian Ministry for Science and Technological Development. The aim of the programme is to strengthen the collaboration between Serbian and German research groups who are working jointly on a particular scientific project.

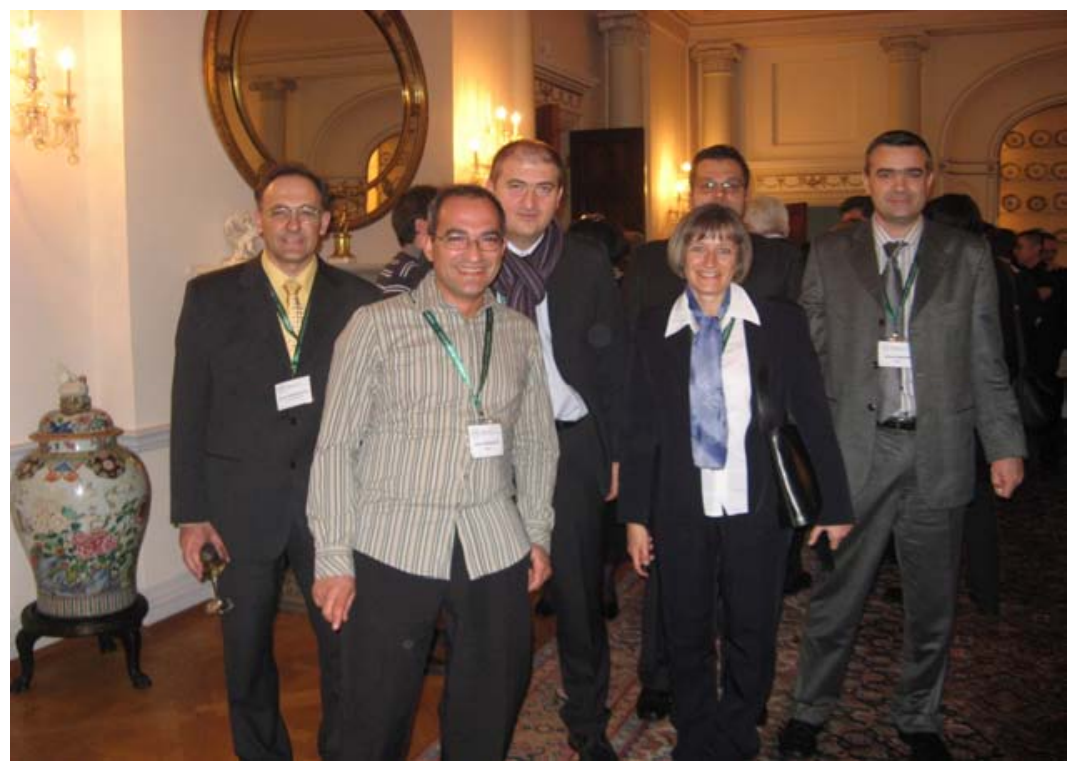

Figure 1 - AvH fellows from Serbia at the Kolleg 2010 in Belgrade (Zoran Radakovic, Goran Vladisavljevic, Srecko Stopic, Ana Kostov, Mirko Komatina)

Slika 1 - Stipendisti Humboltove Fondacije iz Srbije tokom skupa Koleg 2010. godine u Beogradu (Zoran Radaković, Goran Vladisavljević, Srećko Stopić, Ana Kostov, Mirko Komatina)

${ }^{2}$ https://www.daad.de/portrait/wer-wir-sind/kurzportrait/08940.en.html, accessed 26/04/2013. 
Through this DAAD-Programme of bilateral cooperation, IME Process Metallurgy and Metal Recycling of the RWTH Aachen University, Department of Mathematics and Informatics of the University of Kragujevac and Technical and Business College, Uzice, have successfully submitted the project proposal „Artificial Neural Network modelling of silver nanoparticle formation after thermal decomposition of an aerosol" (Figure 2).

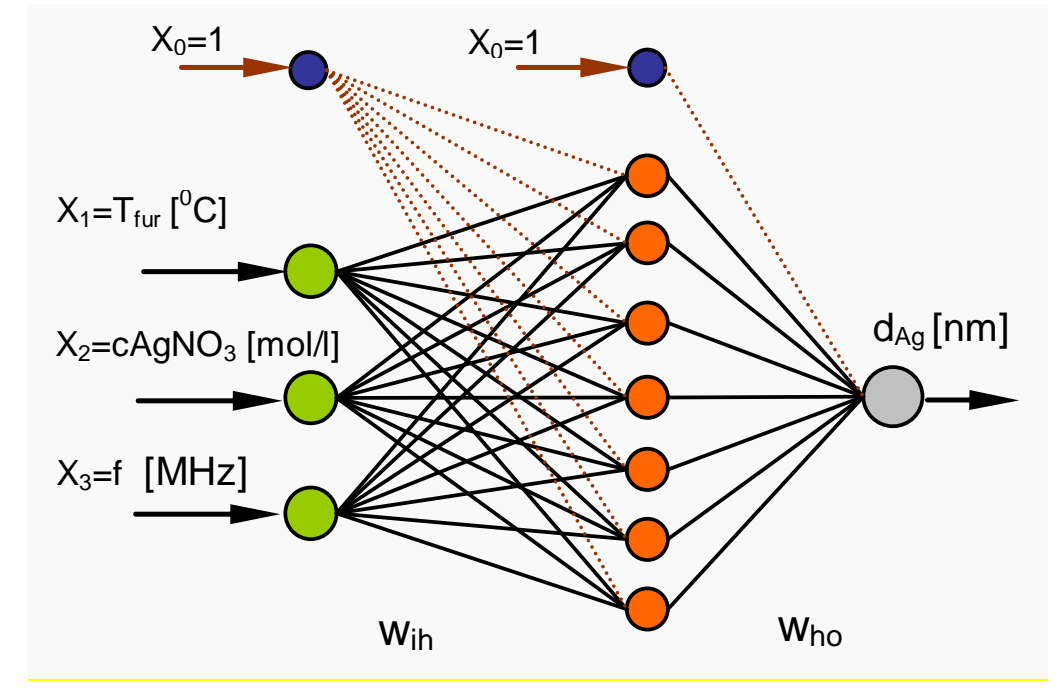

Figure 2 - Neural network modelling of USP-processes (German-Serbian Cooperation) Slika 2 - Modeliranje USP procesa pomoću neuronske mreže (nemačko-srpska saradnja)

The planned cooperation is based on experimental work of the RWTH University (synthesis of nanosized silver by the ultrasonic spray pyrolysis method) and modelling using the regression analysis and neural network by the Institute of Mathematics and Informatics of the University of Kragujevac in Serbia and Technical and Business College, Uzice, Serbia (Optimisation of nanosized silver particles synthesis via an experimental design and an artificial neural network).

A decade of experience in nanoparticle synthesis by USP was the basis to develop a system for industrial scale production in Aachen. The main parts of the demonstration scale Ultrasonic Spray Pyrolysis equipment at the IME, RWTH Aachen University, Germany contain: A) Aerosol ultrasonic generator, B) High-temperature furnace with five wall heated reactors, C) Electrostatic filter, and D) Vacuum system. In cooperation with colleagues from Serbia, five aerosol ultrasonic generators called "Priznano" were built on new equipment. Their design is the result of the joint work between IME researchers, engineers from Elino $\mathrm{GmbH}$, Germany and engineers from PRIZMA Company, Kragujevac, Serbia (Figure 3). 


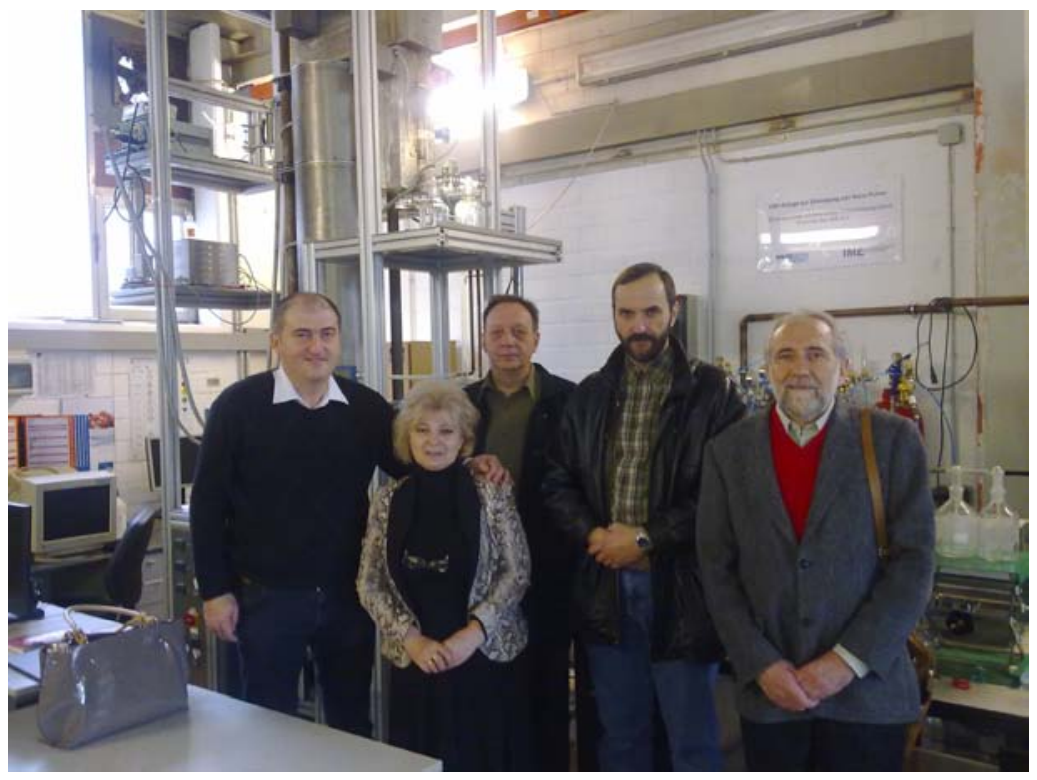

Figure 3 - Srecko Stopic (RWTH Aachen University); Olivera Milosevic (Institute of Technical Sciences of SASA, Belgrade); Sava Maksimovic, Miroslav Ravlic, Nebojsa Pejcinovic (Prizma, Kragujevac) in the laboratory of the IME Process Metallurgy and Metal Recycling of the RWTH Aachen University, Germany (March 21, 2013)

Slika 3 - Srećko Stopić (Univerzitet RWTH Ahen); Olivera Milošević (Institut tehnickih nauka SANU, Beograd); Sava Maksimović, Miroslav Ravlić, Nebojša Pejčinović (Prizma,

Kragujevac) u laboratoriji Instituta za procesnu metalurgiju i recikliranje metala Univerziteta RWTH u Ahenu u Nemačkoj (21. mart 2013)

The main advantages of this system compared to other systems for aerosol production are the small droplet size, established industrial design, continual processability, high corrosion resistivity and the ability to operate with hydrogen (Matula, et al. 2013). From the beginning of this cooperation, Prof. Olivera Milosevic, Institute of Technical Sciences of SASA, Belgrade has supported the realization of this USP-project.

Generally, the key characteristics of the programmes of mobility and exchange between Serbia and Germany are:

- The existence of formal "channels" for achieving scientific mobility - a tradition of international scientific mobility programmes, public announcements for mobility programmes, clear conditions and ways of funding;

- Target groups are scientist who have already achieved something in the academic community and have the possibility to exercise a positive influence in their environment;

- Programmes provide transfer of concrete technologies and research methodologies. 
It is obvious that these programmes may encourage the development of countries of origin by bringing innovation, creating new jobs, improving business operations; creating economic, cultural, social and symbolic capital through global networks; using the advantage of social capital and linguistic understanding; positively linking entrepreneurship and economic development.

\section{Conclusion}

In conclusion, in the short run, emigration of professionals is a loss for the country of origin, and it is brain drain. However, due to the development of telecommunication technologies and transportation, many channels of cooperation have been opened and in the long run there is a chance for brain gain. It should be emphasised that the gap between developing and developed countries related to demographic and economic structure, social conditions and political stability would continue to be favourable for the process of brain drain. Therefore, inclusion of highly qualified migrants into the economic and democratic changes of the home country is necessary. In that way, the achievement of brain circulation will definitely speed up the structural changes (Horvat 2004), and will consequently lead to even greater degree of brain circulation and the formation of the transnational space. In order to achieve these, there is a need for long-term planning, supportive strategic and legal framework, as well as appropriate funds for the implementation of brain gain policies and activities.

\section{References}

Basch, L.G., Schiller, G.N., \& Blanc-Szanton, C. 1994. Nations unbound: Transnational projects, post-colonial predicaments, and deterritorialized nation states..Langhorne, PA: Gordon and Breach.

Beogradski centar za ljudska prava. 2001. Ljudska prava u Jugoslaviji 2000, Pravo i praksa u Saveznoj Republici Jugoslaviji i međunarodni standardi ljudskih prava.Beograd.

Božić, S. 2004. 'Nacionalizam - nacija, 'transnacionalizam' - 'transnacija': mogućnosti terminološkog usklađivanja'.Revija za sociologiju, 35(3-4), pp. 187-203.

Bolčić, S. 2002. Iseljavanje radne snage i "odliv mozgova" iz Srbije tokom 90-tih. In S. Bolčić\& A. Milić Eds., Srbija krajem milenijuma: Razaranje društva, promene i svakodnevni život.Beograd: Institut za sociološka istraživanja Filozofskog fakulteta., pp. 159-168.

Cao, X. 1996. Debating 'Brain Drain' in the Context of Globalisation. Compare: A Journal of Comparative and International Education, 26(3), pp. 269-285. doi:10.1080/0305792960260303

de Haas, H. 2008. Migration and Development, A Theoretical Perspective. In Working paper.Oxford: International Migration Institute.

Docquier, F., \& Rapoport, H. 2011. Globalization, Brain Drain and Development. In Discussion Paper. Bonn: Institute for the Study of Labor. 
Filipovic, J. 2012. Diaspora Virtual University as a Complex OrganizationSerbian Diaspora Virtual University, Germany: Lambert Academic Publishing.

Glick-Schiller, N., Basch, L., \& Blanc-Szanton, C. 1992. Towards a Transnationalization of Migration: Race, Class, Ethnicity, and Nationalism Reconsidered. The Annals of the New York Academy of Sciences, 645, p. 24.

Grečić, V., \& Lopušina, M. 1994. Svi Srbi sveta.Beograd: Princip.

Horvat, V. 2004. Brain Drain. Threat to Successful Transition in South East Europe. Southeast European Politics, 5(1), pp. 76-93.

Kuti, S., \& Božić, S. 2011. Analitičke dimenzije za istraživanje transnacionalnih aktivnosti: primjer kineskih migranata u Hrvatskoj. Revija za sociologiju, 41(3), pp. 315-340.

Kuznetsov, Y. 2006. Diaspora Networks and the International Migration of Skills: How Countries Can Draw on Their Talent Abroad. Washington, DC: The International Bank for Reconstruction and Development. The World Bank.

Matula, G., Bogovic, J., Stopic, S., \& Friedrich, B. 2013. Scale up of ultrasonic spray pyrolysis process for nanopowder production- Part one. In Heat treatment, pp. 46-50.

Morawska, E. 2003. Disciplinary Agendas and Analytic Strategies of Research on Immigrant Transnationalism: Challenges of Interdisciplinary Knowledge. International Migration Review, 37(3), pp. 611-640. doi:10.1111/j.17477379.2003.tb00152.x

Morokvašić, M. 2011. Transnational Mobility of the Highly Skilled: Challenges for Serbia and the Western Balkans. In N. Polovina\& T. Pavlov Eds., Mobility and Emigration of Professionals: Personal and Social Gains and Losses. Belgrade: Group 484., pp. 164-181.

OECD. 2008. A Profile of Immigrant Populations in the 21st Century.

Pavlov, T. 2011. The motivation for migration of highly qualified people in Serbia. In N. Polovina\& T. Pavlov Eds. Mobility and Emigration of Professionals: Personal and Social Gains and Losses. Belgrade: Group 484., pp. 149-163.

Pavlov, T., \& Rakić, D. 2011. Developing Brain Gain Policies in Serbia. Belgrade: Group 484. Policy Paper.

Portes, A. 2003. Conclusion: Theoretical Convergencies and Empirical Evidence in the Study of Immigrant Transnationalism. International Migration Review, 37(3), pp. 874-892. doi:10.1111/j.1747-7379.2003.tb00161.x

Portes, A. 2001. Introduction: the debates and significance of immigrant transnationalism. Global Networks, 1(3), pp. 181-194. doi:10.1111/1471-0374.00012

Portes, A. 1997. Immigration theory for a new century: some problems and opportunities. International migration review, 31(4), pp. 799-825. pmid:12293206. doi:10.2307/2547415

Saxenian, A.L. 2005. From Brain Drain to Brain Circulation: Transnational Communities and Regional Upgrading in India and China. Studies in Comparative International Development, 40(2), pp. 35-61. doi:10.1007/BF02686293

Stopic, S. 2008. Ugledajte se na njih- Neobicne price o uspesnim Ijudima, o kojima se malo zna i retko pise., p. 123.

Stopic, S. 2009. Prodavci znanja- Neobicne price o uspesnim ljudima dijaspore, o kojima se malo zna i retko pise., p. 123. 
Trgovčević, Lj. 2003. The Planned Elite, Students from Serbia in European Universities in the 19th Century. Belgrade: The Institute of History.

Vertovec, S. 2009. Transnationalism. London and New York: Routledge.

Waldinger, R., \& Fitzgerald, D. 2004. Transnationalism in Question. American Journal of Sociology, 109(5), pp. 1177-1195. doi:10.1086/381916

\section{NAUČNA DIJASPORA KAO POKRETAČKA SNAGA ZA RAZVOJ U SRBIJI}

OBLAST: materijali

VRSTA ČLANKA: pregledni članak

Sažetak:

U svetlu savremenih oblika migracija kao i globalizacije i brzog razvoja tehnologija i transporta, dijaspora se sve više posmatra kroz transnacionalnu prizmu. Umesto ne svojom voljom rasejanih zemljaka koji sanjaju o povratku u zavičaj i suočavaju se s problemima integrisanja u zemlji prijema, dijaspora se shvata kao veza između svetova, zemlje porekla i zemlje prijema, koja omogućava da se migracija iskoristi za razvoj zajednice i društva u celini. Umesto na povratku, naglasak je na kružnoj razmeni i transnacionalnoj mobilnosti. Na ovaj način zemlje jugoistočne Evrope pokušavaju da transformišu 'odliv mozgova', naročito izrazit devedesetih godina prošlog veka, u 'kruženje mozgova' i 'dobitak mozgova'. Migracija je u Srbiji devedesetih godina bila izazvana pre svega bekstvom od bolnih i krvavih građanskih ratova na tlu nekadašnje Jugoslavije, međunarodnom izolacijom i NATO bombardovanjem, kao i teškom ekonomskom situacijom. U tom periodu, naročito je bio veliki odliv mladih i obrazovanih ljudi pod parolom 'da diplomiram, pa da emigriram'. Međutim, i posle 2000. godine nastavio se odlazak obrazovanih $i$ stručnjaka, često motivisanih profesionalnim usavršavanjem i razvojem karijere $u$ inostranstvu. Mnogi mladi dobili su priliku da odu u inostranstvo uz pomoć stipendija stranih fondacija koje su imale za cilj da pomognu razvoj u Srbiji, poput Fondacije Aleksander fon Humboldt AvH, nemačke službe za akademsku razmenu DAAD, Fondacije Mumert, i slično. Stoga je glavni cilj ovog rada da utvrdi da li je moguće povezati stručnjake iz dijaspore i mlade studente $i$ inženjere iz Srbije da bi se olakšao transfer znanja i njihova mobilnost i tako sprečio nenadoknadiv gubitak za zemlju. Pored teorijskih razmatranja mogućnosti poboljšanja saradnje s dijasporom, članak analizira jedan primer uspešne saradnje stručnjaka iz metalurške industrije Nemačke i stručnjaka u Srbiji, iniciran od strane predstavnika stručnjaka iz dijaspore. Na kraju se daju preporuke kako da se primene lekcije iz literature i prakse o razvoju održive saradnje stručnjaka iz dijaspore i mladih i stručnjaka u Srbiji.

Ključne reči: naučni potencijal; odliv mozgova; metalurgija; dijaspora.

Datum prijema članka/Paper received on: 19. 05. 2013.

Datum dostavljanja ispravki rukopisa/Manuscript corrections submitted on: 30. 07. 2013.

Datum konačnog prihvatanja članka za objavljivanje/ Paper accepted for publishing on: 02. 08. 2013. 